\title{
RANCANG BANGUN E-COMMERCE BERBANTUAN SMS GATEWAY PADA AUDREY BATIK SUKABUMI
}

\author{
Yusti Farlina ${ }^{1}$, Jamal Maulana Hudin ${ }^{2}$, Ita Yulianti ${ }^{3}$, Marjan Maulana ${ }^{4}$ \\ ${ }^{1}$ Universitas Bina Sarana Infromatika \\ e-mail: yusti.yfa@bsi.ac.id \\ ${ }^{2}$ STMIK Nusa Mandiri Jakarta \\ e-mail: jamal.jml@nusamandiri.ac.id \\ ${ }^{3}$ Universitas Bina Sarana Infromatika \\ e-mail: ita.iyi@bsi.ac.id \\ ${ }^{4}$ Universitas Bina Sarana Infromatika \\ e-mail: marianmaulana95@gmail.com
}

\begin{abstract}
Abstraksi
Audrey Batik adalah perusahaan dagang yang bergerak di bidang penjualan fashion batik. Teknologi informasi memegang peranan yang penting. Pemanfaatan teknologi yang tepat akan menghasilkan informasi yang terkini. Teknologi internet semakin berkembang terutama dalam dunia bisnis, hal ini dapat dilihat dengan munculnya electronic commerce (e-commerce).. Pihak perusahaan Audrey Batik masih menggunakan sistem manual mulai dari pemesanan barang, perhitungan penjualan, perhitungan stok barang dan pembuatan laporan. Hal ini seringkali menimbulkan masalah dalam hal keakuratan data. Audrey Batik belum memiliki sistem yang terkomputerisasi terutama dalam kegiatan penjualannya. Pembuatan web e-commerce merupakan solusi untuk meningkatkan kinerja perusahaan dalam segi peningkatan kualitas informasi dan pemanfaatan waktu yang lebih efisien.
\end{abstract}

Kata Kunci : E-commerce, SMS Gateway, Teknologi informasi

\begin{abstract}
Audrey batik is a trading company engaged in the sale of fashion batik .Information technology plays an important role. Utilization of technology that will deliver the latest information. Internet technology is growing, espiecially in the business world, this can be seen with the advent of electronic commerce (e-commerce). Audrey Batik company is still using manual systems ranging from ordering goods, sales calculation, calculation of inventory and preparing reports. This often creates problems in terms of the accuracy of the data. Audrey batik not have a computerized system, especially in sales activities. To that end, in the final project make the web-based information system for fashion sales. Therefore, e-commerce site creation is a solution to improve the performance of companies in terms of improving the quality of information and a more efficient use of time.
\end{abstract}

Keywords: E-commerce, SMS Gateway, Technology Information

\section{Pendahuluan}

Istilah perusahaan untuk pertama kalinya terdapat di dalam pasal 6 KUH Dagang yang mengatur mengenai penyelenggaraan pencatatan yang wajib dilakukan oleh setiap orang yang menjalankan perusahaan. Meskipun demikian KUH dagang tidak memuat penafsiran otentik mengenai arti perusahaan (Al-Rosyid dkk, 2009).

Untuk memenuhi kebutuhan tersebut, teknologi informasi memegang peranan yang penting, Pemanfaatan teknologi yang tepat akan menghasilkan informasi yang terkini.
Teknologi internet semakin berkembang terutama dalam dunia bisnis, hal ini dapat dilihat dengan munculnya electronic commerce (e-commerce). Dengan membawa keunggulan internet dalam proses bisnis khususnya kegiatan promosi dan layanan pembelian produk, menjadikan e-commerce diaplikasikan oleh banyak organisasi bisnis. Kehadiran e-commerce dalam suatu organisasi bisnis akan memberikan manfaat bagi perusahaan yang mengaplikasikannya. $\mathrm{Hal}$ ini tentunya menjadi keunggulan kompetitif bagi perusahaan (Rudy dkk, 2008). 
Audrey Batik Sukabumi merupakan salah satu perusahaan yang bergerak dalam bidang Fashion batik untuk pria dan wanita (Profil Perusahaan: 2015). Dengan sistem yang berjalan sekarang, masih banyak masalah yang terjadi di pihak perusahaan maupun di pihak konsumen terutama yang berada diluar kota sukabumi. Pihak perusahaan selama ini belum memiliki media khusus untuk mempromosikan produk-produknya. Dan konsumen masih harus langsung datang ke toko apabila ingin mendapatkan informasi produk dan hendak memesan produk sesuai dengan yang diinginkan, serta konsumen harus menghubungi perusahaan via sms/telepon jika ingin mengetahui perkembangan stok dan koleksi terbaru. Audrey Batik Sukabumi memerlukan strategi pemasaran dan penjualan baru yang menjangkau pasar lebih luas sehingga diharapkan dapat meningkatkan penjualan dan memberikan pelayanan yang lebih baik kepada pelanggannya.

Sistem yang baik akan membantu menghasilkan informasi yang cepat dan akurat, Audrey Batik Sukabumi membutuhkan sebuah sistem informasi penjualan online (ecommerce) untuk mempermudah penjualan, pembelian, penyampaian informasi dan akan menjadi sarana komunikasi antara konsumen dengan admin, juga dapat memberikan informasi yang bermanfaat bagi masyarakat umum.

\section{Metode Penelitian}

Metode penelitian dan teknik pengumpulan data yang digunakan dalam penelitian ini, yaitu:

A. Metode Pengembangan Perangkat Lunak Metode penelitian dan teknik pengembangan perangkat lunak pada laporan tugas akhir ini menggunakan model waterfall (Zuniarti, 2012). Metode waterfall terbagi menjadi lima tahapan, yaitu:

\section{Analisis Kebutuhan (Requirement}

Analysis)

Pada tahap ini akan dilakukan pengumpulan semua kebutuhan user yang berkaitan dengan perangkat lunak yang akan dibangun seperti data penjualan, informasi tentang Audrey Batik Sukabumi yang nantinya akan dapat diakses secara online.

2. Desain Sistem (System Design)

Tahapan dalam Perancangan Sistem dan

Perangkat Lunak ERD (Entity

Relationship Diagram), LRS (Logical
Relation Structure) dan struktur navigasi. Sehingga Perancangan Sistem ini tujuannya untuk menggambarkan rancangan sistem baru yang dapat menyelesaikan masalah-masalah yang telah ada pada Audrey Batik Sukabumi. Untuk penyimpanan data menggunakan software database MySQL, untuk membuat rancangan web menggunakan Adobe Dreamweaver CS3 dan Adobe Photoshop CS3.

3. Coding dan Testing (Implementation) Untuk menguji aplikasi yang digunakan berjalan dengan sesuai maka akan dilakukan tahapan setelah diuji dengan blackbox testing, pengujian ini meliputi proses input maupun pengujian proses output, seperti pengujian halaman login, halaman transaksi.

4. Penerapan atau Pengujian Program (Integration \& Testing)

Penyatuan unit-unit sistem kemudian diuji secara keseluruhan (system testing).

5. Pemeliharaan (Operation \& Maintenance) Mengoperasikan dan melakukan pemeliharaan sistem. Upaya pengembangan yang dilakukan untuk meningkatkan kualitas web antara lain dengan melakukan pemeliharaan terhadap web itu sendiri dan melakukan back-up data penting sebelum data web error.

B. Teknik Pengumpulan Data

1. Observasi

Teknik ini dilakukan pengamatan secara langsung pada Audrey Batik Sukabumi untuk mendapatkan berbagai informasi yang berkaitan dengan penjualan Fashion di Audrey Batik Sukabumi.

2. Wawancara

Mengingat betapa pentingnnya kecocokan informasi antara topik yang diangkat dalam tugas akhir ini dengan objek yang dituju, makan dilakukan wawancara dengan pihak terkait yaitu bagian penjualan dan bagian keuangan Audrey Batik Sukabumi.

3. Studi Pustaka

Demi Mendukung informasi yang hendak disajikan pada setiap halaman website, perlu juga dilakukan pengumpulan data dari berbagai macam sumber seperti jurnal, buku, website dll.

3. Hasil dan Pembahasan 3.1. Tinjauan Perusahaan 
Audrey Batik Sukabumi merupakan salah satu perusahaan yang bergerak dalam bidang penjualan fashion batik yang berdiri dan memulai kegiatannya pada tahun 2007. berlokasi di Jl. Cibolang Kp. Cibolang Kaler RT 02/04 Desa Cibolang Kaler Kec Cisaat Kab Sukabumi. Pemilik Audrey Batik Sukabumi adalah Idrus Maulana. Segala sesuatu yang berhubungan dengan penjualan fashion pada Audrey Batik Sukabumi semua dilimpahkan kepada bagian penjualan yakni Abdul Hafid. Dan untuk bagian keuangan dipegang oleh Dita Rosianti selaku bagian keuangan. Audrey Batik Sukabumi hadir untuk memenuhi kebutuhan fashion batik yang dipakai industri serta pertokoan yang tumbuh semakin pesat.

\subsection{Analisa Kebutuhan}

Untuk membuat rancangan website penjualan fashion pada Audrey Batik Sukabumi ini, data yang dibutuhkan diantaranya adalah data produk/fashion beserta harga dan detailnya serta semua yang berhubungan dengan informasi penjualan fashion. Didalamnya terdapat informasi tentang pemesanan secara online, Selain itu pelanggan juga dapat langsung melakukan pemesanan fashion secara online. Untuk bisa melakukan pemesanan tersebut, pelanggan harus memilih produk yang diinginkan kemudian melakukan pendaftaran dengan mengisi registrasi pembelian dengan begitu secara otomatis pelanggan bisa login dengan email dan password yang sudah terdaftar. Setelah itu akan muncul tampilan bukti pemesanan fashion beserta biaya yang harus dibayar. kemudian pelanggan harus segera melakukan pembayaran dan mengkonfirmasikannya kepada admin. Setelah itu, orderan dapat diproses oleh admin. Lalu perusahaan akan segera mengirimkan barang pesanan sehari dari pengkonfirmasian berlangsung. Disediakan pula halaman admin. Sebelum masuk kehalaman admin, maka admin harus melakukan login terlebih dahulu. Pada halaman ini admin dapat melihat data pemesanan. Selain itu admin juga dapat melakukan edit data produk, edit data admin, edit data member.

\subsection{Rancangan Basis Data}

Perancangan basis data dalam penelitian ini dideskripsikan melalui Entity Relationship Diagram yang disajikan pada gambar berikut:

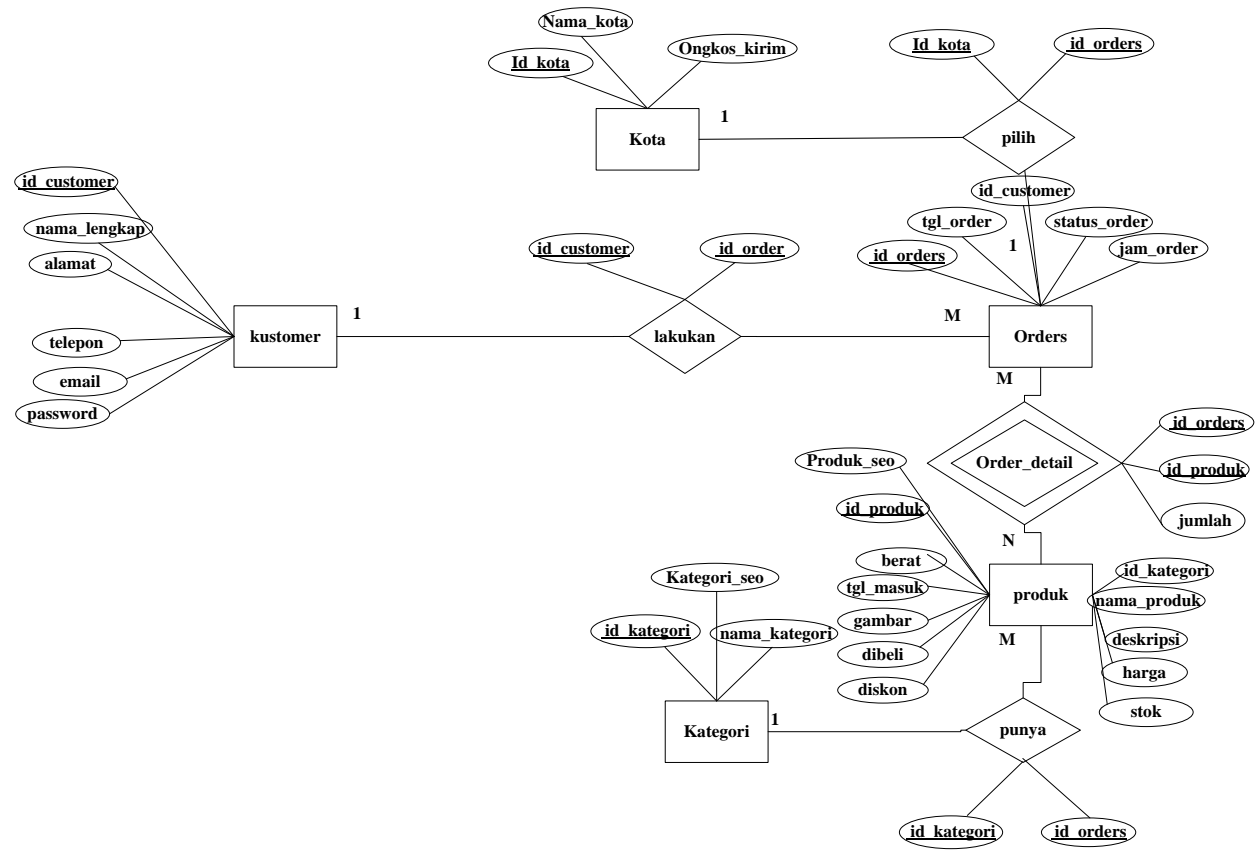

Gambar 1. Entity Relationship Diagram

\subsection{Rancangan Struktur Navigasi}

A. Halaman Front End 


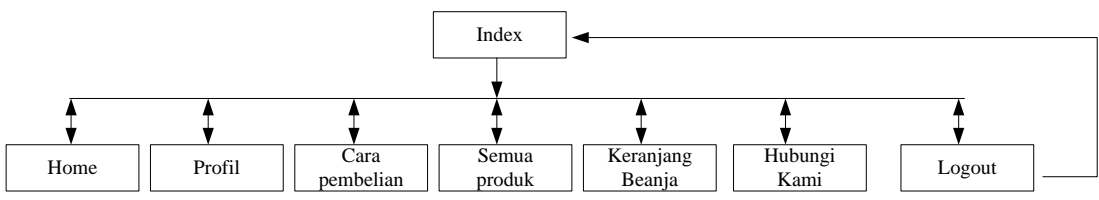

Gambar 2. Struktur Navigasi Halaman Front End

B. Halaman Back End

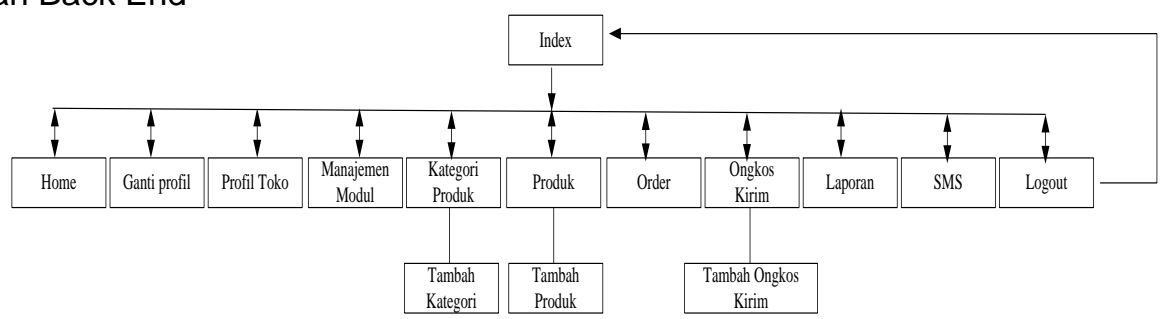

Gambar 3. Struktur Navigasi Halaman Back End

\subsection{Implementasi}

\section{A. Halaman Home}

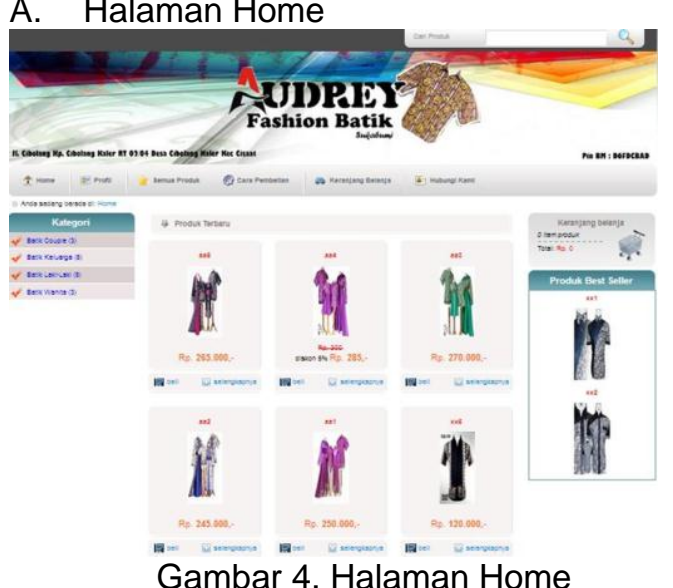

B. Halaman Profil

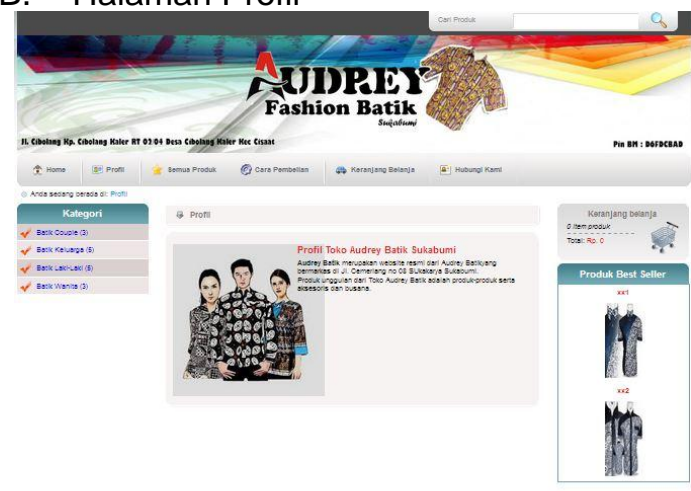

Gambar 5. Halaman Profil

C. Halaman Produk

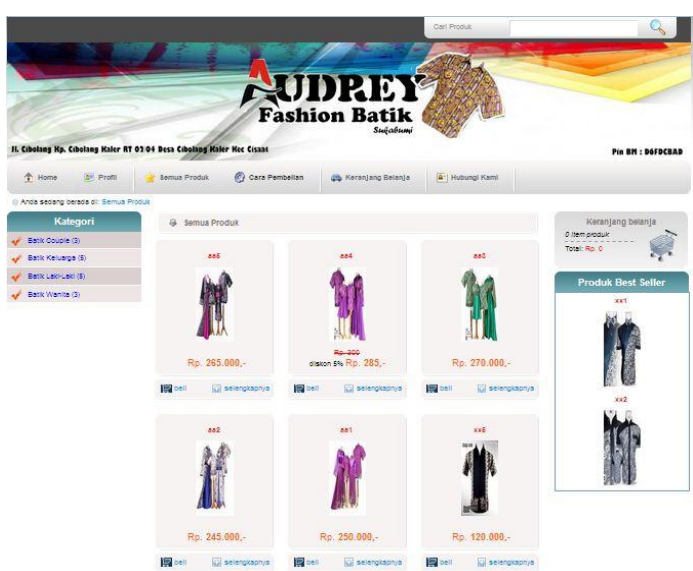

Gambar 6. Halaman Produk

D. Halaman Cara Pembelian

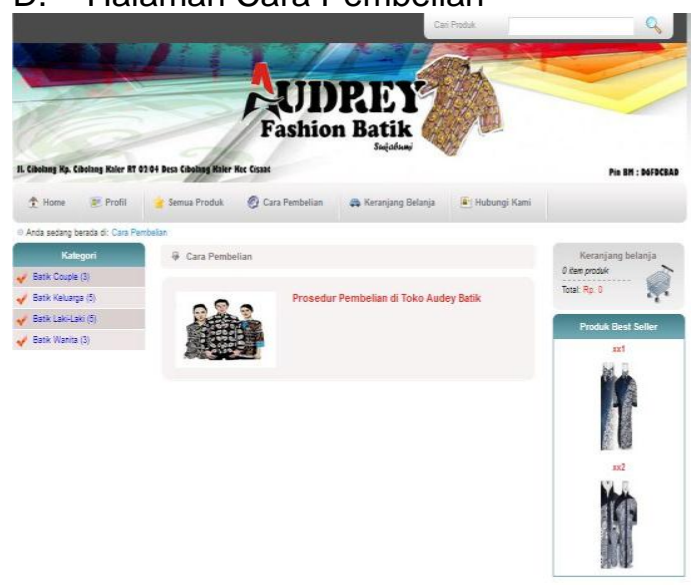

Gambar 7. Halaman Cara Pembelian

E. Halaman Login Admin

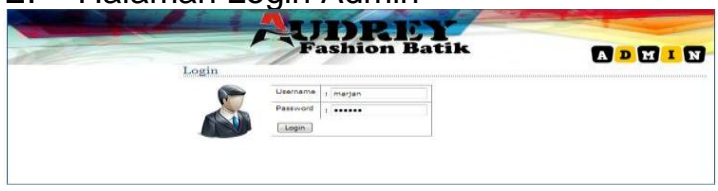

Gambar 8. Halaman Login Admin

F. Halaman Home Admin 


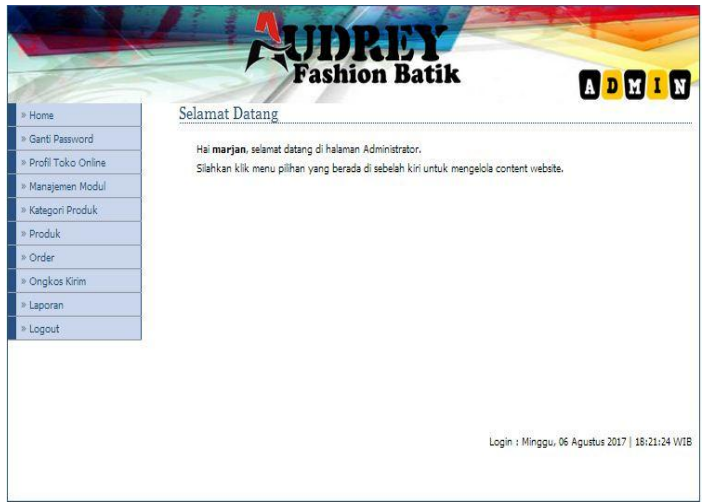

Gambar 9. Halaman Profil

G. Halaman Ganti Password Admin

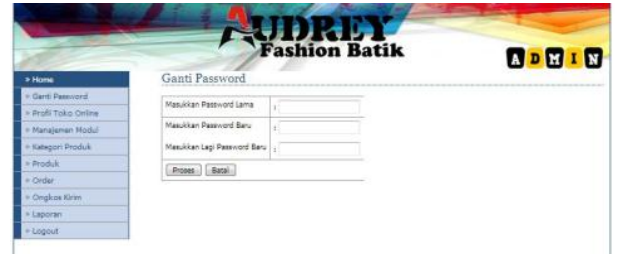

Gambar 10. Ganti Password Admin

H. Halaman Manajemen Modul Admin

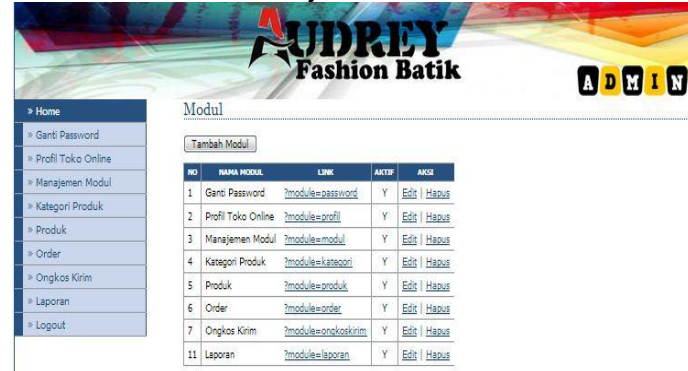

Gambar 11. Halaman Manajemen Modul Admin

I. Halaman Pengelolaan Produk Admin

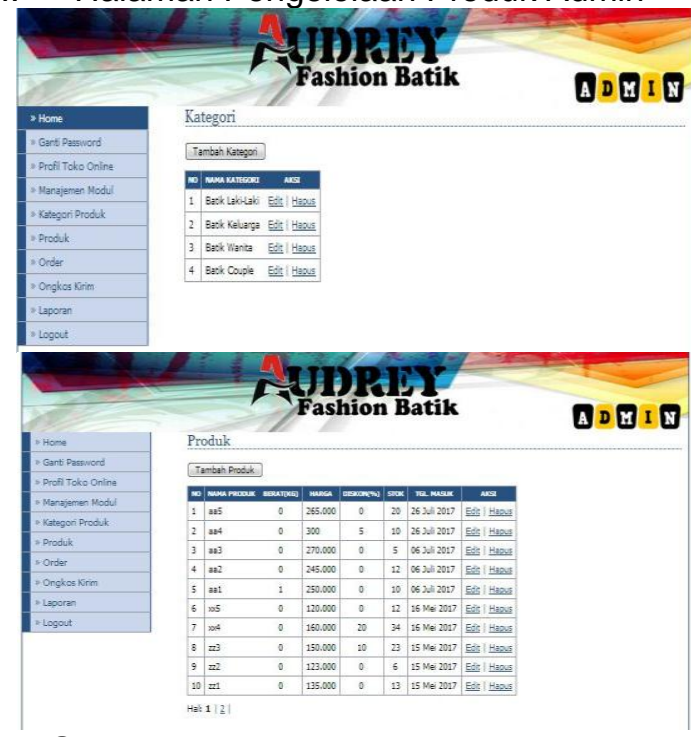

Gambar 12. Pengelolaan Produk Admin

J. Halaman Laporan

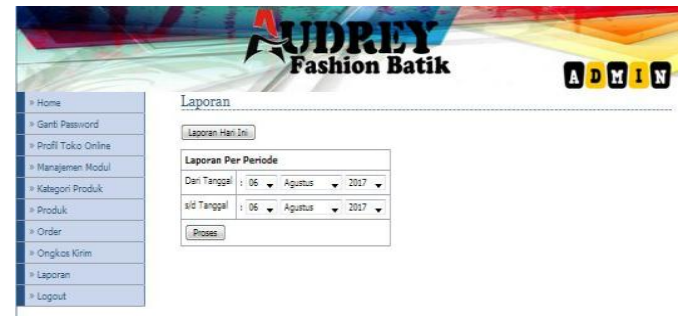

Gambar 13. Halaman Laporan

\section{Kesimpulan}

Setelah memahami, mempelajari, dan mencoba mencari solusi dari permasalahan yang dihadapi oleh Audrey Batik, penelitian ini menghasilkan media promosi, pemesanan dan pembelian berbasis web yang dapat digunakan oleh perusahaan sebagai bentuk pelayanan pemesanan dan pembelian fashion batik sesuai harapan secara online dan media promosi.

Dengan adanya sistem informasi penjualan online berbasis web pada Audrey Batik Sukabumi, maka diharapkan perusahaan tidak mengalami kesulitan dalam mempromosikan, menginformasikan, mengupdate berita terbaru serta melayani pelanggan dan dapat membantu pelanggan dalam melakukan proses pemesanan dengan cepat dan memudahkan pelanggan untuk mendapatkan informasi yang lebih lengkap. Selain itu, penggunaan sistem informasi berbasis web juga dinilai lebih efisien dan efektif dibandingkan proses manual sehingga informasi yang akan disampaikan dapat diakses dengan mudah oleh user, serta update data yang bisa dilakukan kapanpun sesuai dengan keinginan owner.

\section{Referensi}

Al-Rosyid, Harun, Bambang Eka Purnama, and Indah Uly Wardati. 2009. "SISTEM INFORMASI PENJUALAN BUKU BERBASIS WEBSITE PADA TOKO BUKU STANDARD BOOK SELLER PACITAN." IJNS - Indonesian Journal on Networking and Security - ISSN: 2302-5700 - http://ijns.org 1. Hal. 1 - 6

Hutahaean, Japerson. 2014. "Konsep Dasar Sistem." In Konsep Dasar Sistem Informasi, by Japerson Hutahaean, 2. Yogyakarta: CV Budi Utama. 
JURNAL SWABUMI, Vol. 7 No.1 Maret 2019, pp. 14 19

ISSN: 2355-990X

E-ISSN:2549-5178

Maulana, Idrus. (2015, Januari 6). Profil Perusahaan dan Sistem Berjalan pada Audrey Batik Sukabumi. (M. Maulana, Interviewer)

Rudy, Retno Wahyudiarti, Victorani Megaputri, and Ratih Wihardani. 2008. "ANALISIS PERANCANGAN E-COMMERCE (STUDI KASUS: ROEMAH SOETERA BATIK DAN BORDIR)." Seminar Nasional Informatika 2008 (semnasIF 2008) ISSN: 1979-2328 UPN "Veteran" Yogyakarta, 24 Mei 2008. Hal. 226227

Yanto, Robi. 2016. "Entity Relationship Diagram." In Manajemen Basis Data Menggunakan MySQL, by Robi Yanto. Yohyakarta:

Deepublish Publisher

Zuniarti. 2012. "Perancangan Sistem Informasi Penerimaan Mahasiswa Baru." Jurnal IImiah ESAl Volume 6, No.3, Juli 2012 